\title{
Goat type: The key factor to produce goat milk with economic profitable purpose in arid and desert zones
}

\author{
El tipo de cabra: Un factor clave para producir leche de cabra \\ con un propósito económico rentable en zonas áridas y desérticas
}

Juan Scopinich-Cisternas ${ }^{1}$, Erwin Strahsburger ${ }^{1 *}$

\begin{abstract}
Produce goat milk with high standard in arid and desert zones is a difficult mission. The food and freshwater are scarce and high temperatures and low humidity finally affect milk yield. In addition, local cattle rancher has scarce technical knowledge about goat breeding and its management has been transmitted through generation mainly for auto-subsistence. Therefore, What is the first step to move this auto-consuming activity into to a profitable activity with economics gain?. We propose ; through the selection or creation of the right goat type well adapted to this environment and capable of produce between $2-3 \mathrm{~L} \cdot \mathrm{d}^{-1}$ of goat milk with high content of proteins. In this review we analyses the diversity of goat type and its genetics and other productive characteristic over milk production. Especial emphasis about $\alpha \mathrm{S} 1$-casein gene polymorphism, its effect on quality milk and the characteristics of some goat types that habit in arid and desert zones, was discussed.
\end{abstract}

Keywords: Saanen, Creole, Casein, Lactation, Mating, Pregnancy.

\section{RESUMEN}

Producir leche de cabra con altos estándares en zonas áridas y desérticas es una misión difícil. Los alimentos y el agua dulce son escasos y las altas temperaturas y baja humedad afectan finalmente el rendimiento lechero. Además, los ganaderos locales tienen escasos conocimientos técnicos sobre la cría de cabras y sus procesos de manejo han sido transmitidos a través de las generaciones principalmente para auto-subsistencia. Por lo tanto, ¿Cuál es el primer paso para mover esta actividad de auto consumo hacía una actividad productiva con ganancias económicas?. Nosotros proponemos una respuesta; a través de la selección o creación de la cabra adecuada a este ambiente y que produzca entre 2-3 litros de leche por día y con alto contenido de proteína. En esta revisión analizamos la diversidad de tipos de cabra, su genética y otras características productivas sobre la producción de leche de cabra. Especial énfasis fue hecho acerca del polimorfismo del gen aS1-caseina, su efecto sobre la calidad de la leche y las características de algunos tipos de cabra que habitan en zonas áridas y desérticas.

Palabras Claves: Saanen; Criolla; Caseína; Lactancia; Cruza; Preñez.

\section{Introduction}

In many countries goat farming is a good option to support agricultural activities, socially and economically. The reason is the high adaptability of goats to diverse environments and the inclusion of technical management to achieve a maximum productivity (Morand-Fehr et al., 2004). The collaborative work between researchers and farmer communities enable to ensure the improvement of goat breeding managements, especially if local farmer lacks of technical knowledge and most of them are poor families or with scare resources (MorandFehr et al., 2004). Thus, the present review has the intention of contribute to the knowledge about goat breeding with economic purpose in arid and desert zones, discussing the effect of goat type on milk production as a key factor to promote this activity.

\section{The dairy goat type, the key factor for milk production in arid and desert zones}

Arid zones is a place with a range of 0.05 0.65 of the rate of annual precipitation $(\mathrm{P})$ versus

\footnotetext{
1 Molecular Biotechnology Laboratory, Faculty of Renewable Natural Resources. Universidad Arturo Prat, Iquique, Chile.

* Corresponding author: estrahsb@unap.cl
} 
potential evapotranspiration (PET), meanwhile in hyper-arid or desert zone this rate is $<0.05$. The Atacama Desert located at north of Chile is extended through three political regions and is classified as arid or desert zones according to the precise site of the location. Nevertheless, in this desert many agricultural practices are done and many of them contribute with agricultural products to local markets. Goat farming is one of these activities but with unsuccessfully results with unprofitable activity because high volumes of goat milk are not produced to satisfy the local markets. To solve this problem some efforts has been made like the introduction of dairy goat type in local herd or the use of alternatives diet to improve the milk production in creole goats. However, we propose another solution, the selection or creation of a convenient goat type for milk production with adaptability skills for living in desert and arid zone as the key factor to trigger this activity in goat farming with profitable gains.

Goat genus belongs to the order of split hoof Artiodactyla, Ruminant suborder, Bovidae family, Caprinae subfamily. This genus comprise about 570 types of goats that habitat in different places and shows differences in its sanitary and feed requirements, adaptability to natural environments and milk production. Therefore, many options to choose a right goat type for milk production in arid and desert zone are available. However, the general tendency is select some goat breeds that come from three Europe countries; Sweden (Saanen and Toggenburg), France (Alpine) and England (Anglo-Nubian). These breeds produce between 2-3.4 L per day of milk and most of them come from mountain or Mediterranean weather, while Nubian breed came from desert zones with a milk production around 1.-2,9 L per day. However, Have these goat breeds the ability to produce milk in arid or desert zones?. At first sight the Nubian goat seem the most appropriate for breeding in arid and desert zones. In general, a change in the environment can affect milk production according to the new geographical characteristic and changing in the farming ecosystem, and is expected that dairy goats well adapted can keep their highly milk production rate (Diaz et al., 2011). In consequence, this new particular environment, the goat type and the feeding and breeding strategies will defined the maximum volume of milk to produce for this new introduced herd.
The introductions of dairy goat that originally come from mountains or Mediterranean weather did not necessary assure a good milk production in arid and desert zones. For example, Olave and colleagues (2009) reported the experience of improving local herd introducing Saanen goats into the Pampa of Tamarugal, a desert zone located within the Atacama Desert area. At the beginning, the Saanen herd produced almost 2 liters of milk at 10 days after the parturition but followed by a gradually reduction until produce 0.5 liters at 100 days. That was a 77\% less than a similar herd located in the central zone of Chile, a place with Mediterranean weather (Olave et al., 2009). This study clearly demonstrates the relevance of goat's adaptability skills for a new environment to keep up the milk production. Otherwise, the introduced goat breed will be unable of achieve its maximum milk production in this new environment.

Therefore, Which is the right goat type for arid and desert zones?. May be is a creole goat or a hybrid goat (the offspring between a creole goat and a dairy goat). In milk goat farming creole goats are frequently discarded due to their lower milk production. However, when genetics or productive studies were done on creole goats from Greece, Italy and Indian, the conclusion were different. They were considered as a good milk producer and hence, a good alternative for local goat rancher (Marletta et al., 2005; Kumar et al., 2007). In Mexico another study demonstrated the potential of creole goats in milk production. Their milk productivity increased form $0.65 \mathrm{Kg} \cdot \mathrm{d}^{-1}$ to $1.14 \mathrm{~kg} \cdot \mathrm{d}^{-1}$ after change the pasturing farming for a stall feed system (Maldonado-Jaquez et al., 2017). Thus, the ignorance about the potential high milk production encoded in the genome of creole goats, or their appropriate breeding conditions to achieve its maximum productivity is a barrier to overcome in local farmers, promoting the inclusion of creole goats in milk production, instead of introduction of traditional dairy goats that finally are not well adapted for desert and arid zones.

The crossbreeding between dairy and creole goats is also another good alternative (Kume et al., 2012; Sanogo et al., 2012). Creole goats have adaptive traits for arid and desert zones, like walking for long time to cover broad natural forage area. This and others traits like the rusticity characteristic are expected to heritage after crossbreeding strategies (David et al., 2016) and the inclusion of genetic 
marker to select the best parental goats and check the presence of these markers in the newborn offspring is the best strategy to maintain a high productive herd for a long time. The absence of genetic markers obey to evaluate the milk production in the $\mathrm{F} 1$ and F2 generation and perform new crossbreeding until found the best productive goat in a longer and laborious process. For example, the crossbreeding between creole and Saanen goats at central zone of Chile produced a F1 descendants with high and low milk yield characteristics. However, when crossbreeding was performed with the best milk producers of F1 and Saanen breed, all F2 generation showed an improvement in milk production (Jahn, 2001). In the Coquimbo region (IV region) Chilean creole goat was crossbreed with Saanen, AngloNubian and Toggenburg breeds, and similar results were obtained. The hybrid goats produced more of $138 \mathrm{~L}$ of milk volume than creole goat (Meneses, 2012). In Venezuela a crossbreeding between creole goats and Alpine, Toggenburg and Nubia goats also showed more milk production and an extension of the lactation period in one month in hybrid goats. The best productive hybrid goat was that from the crossbreeding between the Creole and the Alpine goat (García et al.,1996). In all these studies, the heritage of rustic characteristics on the next hybrid generation was not reported, probably because these are not relevant to rearing dairy goats or because they are not still determined.

In creole goats of desert and arid zones, the heritage of features required to live in harsh environments is an important matter. At north of Chile, the most goats are creole types and were brought from Spain by Spanish conquers. These goats usually do not required much care and produce around 0.5 Liters of milk daily, being good for subsistence purpose in the conquers time but not enough for a productive activity in current times. Therefore, as mentioned before, a possible solution is the crossbreeding between desert creole goat and dairy goats to obtain a hybrid goat well adapted to desert condition and with high milk productivity. In fact, local agricultural campaigns where researcher supports local farmers through the use of genetic markers to find the best hybrid dairy goat could reduce time and cost to achieve this final goal (Echeverri et al., 2014). However, Which is the best genetic markers? We suggest the $\alpha$ S1-casein gene because have a polymorphism well correlated with the goat milk quality.

\section{High milk quality, another challenge for goat breeding in arid and desert zones}

Milk is the liquid secreted by the mammary glands of female mammals to satisfy the nutritional needs of the new born until could eat by itself. In humans, milk is considered a supplementary food when comes from animal source like; cow, goat, donkey and others mammals. Thus, milk is an important source of carbohydrates, lipids, proteins, vitamins, minerals and immune defense factors, and cow milk is the most demanded. Although goat milk is considered better than cow milk in many nutritional aspects, still has a minor market position without notorious change in consumer's habits to improve its demands.

Goat milk content can change according to the goat breed and feeds diet, but usually not change too much because goats are highly efficient in convert the uptake food in milk. In Mexico, a study evaluated the change in milk composition between goats with stall feed regimen with integral diet versus goats with traditional pasturage with or without supplemental diet. The stalled goats with integral diet increase its protein, lactose and milk production in $8 \%, 4 \%$ and $78 \%$, respectively, in comparison with grazing goats. When grazing goats was fed with integral diet (1000 grams), protein and lactose content increased in around $6 \%$ and the milk yield in $200 \%$ respect to grazing goats without supplemental diet (Maldonado-Jaquez et al., 2017). In summary, milk quality did not change too much between stalled and grazing goats $(<10 \%)$, because is the same goat under different managements conditions, because milk quality is defined mainly genetically. In consequence, this study suggest a good commercial opportunity for local farmers because can sell more volume of high quality milk just changing the managements procedures of goat breeding.

In summary, the evolution through the heritage of some genetic factors, assure high quality milk under different diet conditions to provide a minimal content of protein, lactose and other nutritional factors in the goat milk. This feature is based on the capacity of reduce the volume of milk to concentrate these nutritional factors, assuring a high quality milk under less nutritional diets. In this sense, the energetic conversion of uptake food in milk is driven mainly to sustain the milk quality over the milk volume, warranting the normal growth of the newborn kid. 
The goat milk content is enriched in vitamin A, riboflavin, growth factors and short chain fats like capric, caproic and caprilic acid. These fat are metabolized to produce energy instead of lipid synthesis and contribute to limit and dissolve serum cholesterol preventing coronary disease, cystic fibrosis and gallstone (Park et al., 2007). Besides, these lipids reduce the body weight by three mechanisms; promote lipid oxidation, reduce lipogenesis, and trigger cetonic body synthesis (Park et al., 2007). On the other hand, goat milk lacks of agglutinin, the protein that agglutinate lipids corpuscle inducing bigger bulbs. That lacks confers milk with more dispersive bulbs, which are easily metabolized by digestive enzymes, improving its digestibility (Kondyli et al., 2012). Finally, goat milk has low allergen content, preventing the cow's milk protein allergy. That disease affects to $2-3 \%$ of kids below 3 years old, and has a social and economic impact due to expensive cost of its low $\alpha$-casein milk formulas. However, goat milk could have low $\alpha$-casein content naturally, being a cheap alternative to provide milky product with hypoallergenic properties (Sáez et al., 2016).

Thus, the benefits of goat milk on human health constitute an economic opportunity to promote goat milk production in arid and desert zones, but only if a high volume of high quality milk is produced after selected the best goat type and the more productive management conditions. A good example is the goat milk production by Black Bedouin goat in the Negev desert of Israel. This goat has a great adaptability to produce high quality and high volume of milk in desert zones reaching between 0.95 to $1.561 \mathrm{Kg}$ of milk per day during first lactation period using early goats (1-2 years old) and around $1.640 \mathrm{Kg}$ of milk per day using mature goats (3 to 7 biological years) (Maltz and Shkolnik, 1980). A similar result was described for Beetel goat in Pakistan, where mature goats produce more milk than early goats during first lactation period (Waheed and Khan, 2013). Regarding milk quality in Black Bedouin goat, during its first four lactation periods, the content of protein, fat and lactose were stable and around of $3.5 \%, 5.5 \%$ and $5 \%$, respectively (Shkolnik et al., 1980). In fact, Black Bedouin goat is probably the most efficient goat in milk production (Maltz and Shkolnik, 1980). Although in many goats the heat stress reduces the food intake and affects milk production. In goats well adapted to dry and hot conditions, they still produce high milk yield being so far the best farming practice to produce milky products and obtain profits in a desert and arid zones.

\section{Genetics Factors}

Genes of milk proteins are located on chromosome 6 in a segment of $250 \mathrm{kbps}$, are highly conserved in mammals, and polymorphic between and within species (Selvaggi et al., 2014.). The main proteins found in milk are six: alpha-S1, alpha-S2, Beta and Kappa casein (represented as $\alpha$ s1, $\alpha \mathrm{s} 2, \beta$ and $\kappa$-casein) and lactoserum proteins; $\beta$-lactoglobulin and $\alpha$-lactalbumin. Between them, caseins proteins are the major component of goat milk proteins (76$86 \%$ of the total protein content) (Selvaggi et al., 2014.). In nutritional and technological aspect, caseins are a rich source of essential amino acids and the key component in milk coagulation process during cheese production. A high content of casein contribute to induce a better coagulation process, promote a curd with better density, reduce the time of coagulation, and induce a production of more vigorous clot to be used then in cheese production.

The $\alpha$ S1-casein gene has the highest variability between all casein genes and its differences in their genetic expression is related with a genetic polymorphism classified as "strong or high", "intermediate", "weak" and "null" in terms of content of as1-casein in milk (Marletta et al., 2007). The advances in diverse technologies to detect this polymorphism have allowed the development of dairy products with specific nutraceutical properties or the improvements in cheese production or others milky products (Marini, 2015). In fact, in Saanen goat only the total protein content was different between higher and null as1-casein genotype, while fat levels did not show any statistical differences (Caboni et al., 2016). In the same way, in Sicilian goats; Girgentana y Argentata dell'Etna a genetic polymorphism study on $\alpha$ s1-casein gene showed their potential in milk production identifying the "strong" alleles as homo or heterozygote genotype with the null allele (Marletta et al. 2005). In consequence, these goats are a good alternative to renew local herd and promotes the protection of native goat species (Marletta et al. 2005). In Indian goats breeds; Beetal, Jamunapari, Chegu and Jakhrana, similar results were observed. The genetic study shows the presence of strong allele of 
as1-casein gene (allele A and B), promoting these breeds as a good alternative for milk production and encouraging their conservation as native animal (Kumar et al. 2007).

The discussion above shows the relationship between the polymorphism of $\alpha$ s1-casein gene and the milk protein concentration. Hereof, typical dairy goats characterized for produce milk with high protein content, should have at least a strong or intermediate as1-casein genotype. However, this polymorphism is variable even in dairy species like Saanen or Alpine goat (Hayes et al., 2006). In the Northeastern of Brazil a study about milk composition produced by Saanen and Alpine breeds shows the lack of as1-casein protein, but similar concentration of the others caseins proteins ( $\alpha \mathrm{s} 2, \beta$ and $\kappa$-casein) (Da Costa, 2014). Although they did not perform a genetic study, the results strongly suggest the presence of homozygotes null alleles of as1-casein gene, and positioned this milk as a good alternative for people with cow's milk allergy.

In summary, high quality milk have a high proteins concentration but a high volume of milk not necessary involves a high content of as1-casein protein. The use of genetic marker to determine their as1-casein gene polymorphism could help to determine the goat potential as an animal producer of milk with a high content of protein, especially if the main purpose is produce dairy products like cheese. In crossbreeding strategies, the use of genetic markers could contribute to select the best parental goats and best offspring to keep up this milk productivity.

\section{Conclusion}

In conclusion and according to the literature is totally possible produce high volume of high quality milk and obtain profitable gains in arid and desert zones. The selection of goat type is crucial and a goat highly efficient to convert food in milk and well adapted to dry and hot conditions, is preferred. Creole goat could be a good alternative due to their adaptive skills for this environment and because is still an unexplored animal as milk producer at north of Chile. Crossbreeding strategies between this animal and goat breed characterized for a high quality milk production could help to obtain an offspring of hybrid goat well adapted to arid and desert zones and better producer of high quality milk, as well. The use of molecular markers like $\alpha$ S1-casein genes to select those animals with more potential as producer of high quality milk is recommended. Moreover, this genetic marker is a good tool to unify the breeding criteria about the goat type needed for milk production and to sustain a good quality herd along the time. Thus, local famers can permanently produce high quality milk and dairy products to commercialize in local or international markets and with profitable gains, from an agricultural activity performed in desert and arid zones.

\section{Literature Cited}

Caboni P.; Murgia, A.; Porcu, A.; Demuru, M.; Pulina, G.; Nudda, A.

2016. Gas chromatography-mass spectrometry metabolomics of goat milk with different polymorphism at the $\alpha \mathrm{S} 1$ casein genotype locus. Journal of Dairy Science, 99: 6046-6051.

Da Costa, W.K.A.; de Souza, E.L.; Beltrao-Filho, E.M.; Vasconcelos, G.K.V.; Santi-Gadelha, T.; de Almeida Gadelha, C. A.; Magnani, M.

2014. Comparative protein composition analysis of goat milk produced by the Alpine and Saanen breeds in northeastern Brazil and related antibacterial activities. PloS one, 9: e93361.

David, R.N.; Abdala, G.C.; Abdala, M.E.; Lescano, J.A. 2016. Empleo del análisis multivariado en la evaluación de factores no genéticos de cabras Criollas. Arch. Zootec., 65: 197-202.

Diaz, I.D.P.S.; Oliveira, H.N.D.; Bezerra, L.A.F.; Lobo, R.B. 2011. Genotype by environment interaction in Nelore cattle from five Brazilian states. Genetics and Molecular Biology, 34: 435-442.
Echeverri, J.; Rincón, J.C.; López-Herrera, A.

2014. Estimation of genotype-by-environment interaction for milk traits based on foreign sires used in Colombia. Revista Colombiana de Ciencias Pecuarias, 27: 245-252.

García, O.; García, E.; Bravo, J.; Bradford, E.

1996. Análisis de un experimento de cruzamiento usando caprinos criollos e importados. VII. Producción de leche y evaluación de grupos raciales. Revista de la Facultad de Agronomía (LUZ), 13: 611-625.

Hayes, B.; Hagesæther, N.; Ådnøy, T.; Pellerud, G.; Berg,

P.R.; Lien, S.

2006. Effects on production traits of haplotypes among casein genes in Norwegian goats and evidence for a site of preferential recombinati on. Genetics, 174: 455-464.

Jahn E.

2001. Producción de leche con distintos genotipos de cabra. INIA, 66: 109-117.

Kondyli, E.; Svarnas, C.; Samelis, J.; Katsiari, M.C.

2012. Chemical composition and microbiological quality of ewe and goat milk of native Greek breeds. Small Ruminant Research, 103: 194-199. 
Kumar, A.; Rout, P.K.; Mandal, A.; Roy, R.

2007. Identification of the CSN1S1 allele in Indian goats

by the PCR-RFLP method. Animal, 1: 1099-1104.

Kume, K.; Papa, L.; Hajno, L.

2012. Effects on milk production in F1 crossbred of Alpine goat breed $\left(\sigma^{\top}\right)$ and Albanian goat breed ( + ). Italian Journal of Animal Science, 11: e47.

Maldonado-Jaquez, J.A.; Granados-Rivera, L.D.; HernándezMendo, O.; Pastor-Lopéz, F.J.; Isidro-Requejo, L.M.; Salinas-González, H.; Torres-Hernández, G.

2017. Uso de un alimento integral como complemento a cabras locales en pastoreo: respuesta en producción y composición química de la leche. Nova Scientia, 9: 55-75.

Maltz, E.; Shkolnik, A.

1980. Milk production in the desert: lactation and water economy in the black Bedouin goat. Physiological Zoology, 53: $12-18$

Marini, P.R.; Castro, R.; Frana, E.; Di Masso, R.J.

2015. Eficiencia biológica de biotipos lecheros de primera lactancia en sistemas a pastoreo. Rev. Vet., 26: 136-142.

Marletta, D.; Bordonaro, S.; Guastella, A.M.; Criscione, A.;

D’Urso, G.

2005. Genetic polymorphism of the calcium sensitive caseins in sicilian Girgentana and Argentata dell'Etna goat breeds. Small Ruminant Research, 57: 133-139.

Marletta, D.; Criscione, A.; Bordonaro, S.; Guastella, A.M.;

D'Urs, G.

2007. Casein polymorphism in goat's milk. Lait, 87: 491-504.

Meneses, R.

2012. Cruzamiento caprino para incrementar el potencial productividad de los animales. Tierra Adentro, 103: 55-58.
Morand-Fehr, P.; Boutonnet, J.P.; Devendra, C.; Dubeuf, J.P.;

Haenlein, G.F.W.; Holst, P.; Mowlem, L.; Capote, J.

2004. Strategy for goat farming in the 21 st century. Small Ruminant Research, 51: 175-183.

Olave, J.; Canales, T.; Meneses, M.

2009. Introducción de cabras lecheras Saanen a la pampa del Tamarugal para el mejoramiento del ganado local. INIA, 197: 130-134.

Park, Y.W.; Juárez, M.; Ramos, M.; Haenlein, G.F.W. 2007. Physico-chemical characteristics of goat and sheep milk. Small Ruminant Research, 68: 88-113.

Sáez, L.; Olivera, C.; Díaz, C.

2016. Percepción del uso de leche de cabra como parte del tratamiento a la alergia a la proteína de leche de vaca (APLV) en la región Metropolitana, Chile. Avances en Ciencias Veterinarias, 30: 24-29.

Sanogo, S.; Shaker, M.M.; Nantoumé, H.; Salem, A.F.Z.

2012. Milk yield and composition of crossbred Sahelianx Anglo-Nubian goats in the semi-intensive system in Mali during the preweaning period. Tropical Animal Health and Production, 45: 305-310.

Selvaggi, M.; Laudadio, V.; Dario, C.; Tufarelli, V.

2014. Major proteins in goat milk: an updated overview on genetic variability. Molecular Biology Reports, 41: 1035-1048.

Shkolnik, A.; Maltz, E.; Gordin, S.

1980. Desert conditions and goat milk production. Journal of Dairy Science, 63: 1749-1754.

Waheed, A.; Khan, M.S.

2013. Lactation curve of Beetal goats in Pakistan. Archiv Tierzucht, 56: 892-898. 